\title{
Antioxidant and neuroprotective potential of extract of Brazilian pine Araucaria angustifolia bracts against oxidative stress induced by sodium azide in hippocampus of rats
}

\author{
Fernanda de Souza Machado ${ }^{1}$, Jonnsin Kuo ${ }^{1}$, Bárbara Roberta Ongaratti ${ }^{1}$, Niara da Silva Medeiros ${ }^{1}$, Mirian Salvador ${ }^{2}$, Caroline Dani ${ }^{1}$ and \\ Cláudia Funchal ${ }^{1 *}$ \\ ${ }^{1}$ Centro Universitário Metodista-IPA, Rua Coronel Joaquim Pedro Salgado, 80 - Rio Branco, 90420-060 Porto Alegre, Brazil \\ ${ }^{2}$ Universidade de Caxias do Sul, Caxias do Sul, Rua Francisco Getúlio Vargas, 1130 - Petrópolis, 95070-560 Caxias do Sul, Brazil
}

\begin{abstract}
The aim of this study was to evaluate the in vitro antioxidant and neuroprotective potential of the extract of Araucaria angustifolia bracts (AAE) against cell viability changes and oxidative stress induced by sodium azide in the hippocampus of rats. Hippocampal homogenates were pre-incubated for $30 \mathrm{minutes}$ with $10 \mathrm{mg} /$ $\mathrm{mL} \mathrm{AAE}$ and then incubated for 60 minutes with $5 \mathrm{mM}$ sodium azide. The homogenates were then assayed for thiobarbituric acid reactive substances (TBARS), carbonyl, sulfhydryl, catalase (CAT), superoxide dismutase (SOD) and nitric oxide (NO). The results showed that sodium azide enhanced TBARS levels, CAT activity and NO production. Sodium azide also reduced sulfhydryl content and SOD activity. AAE prevented the changes in TBARS, CAT, SOD and NO. Cell viability was evaluated by lactate dehydrogenase $(\mathrm{LDH})$ release and the 3(4,5-dimethylthiazol-2-yl)-2,5-diphenyl tetrazolium bromide (MTT) reduction. Sodium azide did not change LDH levels or MTT reduction. However AAE reduced LDH release and increased MTT reduction in the presence or absence of sodium azide. Therefore, AAE has potential antioxidant and neuroprotective activity in the rat hippocampal homogenate.
\end{abstract}

\section{Introduction}

Plants have played a part in human life since its beginning, and its importance in the various developmental stages of society is undeniable. The products made from plants can be used as prototypes for the development of pharmaceutical products [1]. Furthermore, the use of plant products is related to the reduction in risk of various chronic diseases, where those beneficial effects are generally attributed to compounds that have antioxidant properties, such as phenolic compounds $[2,3]$.

Araucaria angustifolia (Bert.) O. Kuntze (Araucariaceae) is a native conifer that grows naturally in southern Brazil and Northwestern Argentina, and is popularly known as "pinheiro-do-paraná" or "pinheiro-brasileiro" [4]. It is a dioecious species, which means it features male and female individuals that have their own distinct strobilus. The female strobilus consists of seeds (the edible part of A. angustifolia) and bracts, which are undeveloped seeds commonly discarded into the environment [5].

According to the Brazilian Institute of Geography and Statistics (IBGE), the quantity of $A$. angustifolia produced in the southern Brazil in the state of Rio Grande do Sul in the year of 2010 was 749 tons, with Serra Gaucha being the biggest producer of Brazil [6]. A. angustifolia has about $89.3 \%$ bracts (sterile seeds), which are discarded into the environment, where there is no known use described for this part of the plant until now [7].

Accordingly, different parts of A. angustifolia are used in Brazilian folk medicine, such as infusions of bark used to treat muscle strains and varices, the syrup produced from resin used to treat respiratory tract infections, and infusions of leaves used to treat scrofula, fatigue, and anemia [8]. Despite these traditional practices, few phytochemical and pharmacological studies have been performed with A. angustifolia. Recently, it was described that the aqueous extract of bracts from $A$. angustifolia (AAE) is rich in catechin, epicatechin and rutin, phenolic derivatives from the flavonoid family, which have antioxidant properties [7].

Therefore, considering that AAE contains high levels of polyphenols and that these bioactive compounds can act as scavenging agents, minimizing the generation of reactive species and free radicals [9-12], which are implicated in protein, lipid, and nucleic acid damage and the appearance of several diseases associated with oxidative stress, such as cancer, cardiovascular and neurological diseases $[13,14]$. The aim of this study was to evaluate the in vitro antioxidant and neuroprotective effects of AAE on cell viability changes and oxidative stress induced by sodium azide in the hippocampus of Wistar rats.

Correspondence to: Dr. CláudiaFunchal, Centro Universitário Metodista - IPA Rua Cel. Joaquim Pedro Salgado, 80 90420-060 - Porto Alegre - RS, Brazil, Tel: 55 5133161233, E-mail: claudia.funchal@metodistadosul.edu.br; csfunchal@yahoo.com.br

Key words: Araucaria angustifolia, antioxidants, oxidative stress, reactive species

Received: January 20, 2015; Accepted: February 16, 2015; Published: February 20,2015 
Machado FS (2015) Antioxidant and neuroprotective potential of extract of Brazilian pine Araucaria angustifolia bracts against oxidative stress induced by sodium azide in hippocampus of rats

\section{Materials and methods}

\section{Materials}

All chemical reagents were purchased from Sigma (St. Louis, MO, USA), except for thiobarbituric acid, which was from Merck (Darmstadt, Germany). The commercial kit for lactate dehydrogenase (LDH) assay was obtained from Doles Reagentes (Goiânia, GO, Brazil).

\section{Plant material and preparation of the extract}

Pines of A. angustifolia were collected in Caxias do Sul, Rio Grande do Sul (29 $\left.10^{\prime} 05^{\prime \prime} \mathrm{S}, 51^{\circ} 10^{\prime} 46^{\prime \prime} \mathrm{W}\right)$, Brazil, in 2011. Voucher specimens were identified by the herbarium of the University of Caxias do Sul, Rio Grande do Sul, Brazil (HUCS36536). Bracts were manually separated and mixed to obtain a pool, which was used to prepare the extract. Bracts were dried in an air oven at $37^{\circ} \mathrm{C}$, milled (Tecnal model Willye TE-650) and mixed with distilled water (5\%,w/v). Extraction was done under reflux $\left(100^{\circ} \mathrm{C}\right)$ for 15 minutes, as described by Michelon et al. [7]. After cooling to $25^{\circ} \mathrm{C}$, AAE was filtered with Millipore equipment (pore size, $0.45 \mu \mathrm{m}$; catalog number SFGS 047LS, Millipore Corp., São Paulo, Brazil), lyophilized (LIOBRAS model L-101), and stored in the dark. Before each assay, the lyophilized powder was resuspended in water. HPLC analysis of the AAE demonstrated that the major compounds of the extract were catechin $(140.6 \pm 2.86 \mathrm{mg} / 100 \mathrm{~g}$ bracts $)$, epicatechin $(41.3 \pm 2.73 \mathrm{mg} / 100 \mathrm{~g}$ bracts $)$, quercetin $(23.2 \pm 0.06 \mathrm{mg} / 100 \mathrm{~g}$ bracts $)$ and apigenin $(0.6 \pm 0.06 \mathrm{mg} / 100 \mathrm{~g}$ bracts) [5].

\section{Animals}

Ten Wistar rats (10-days-old) were obtained from our own breeding colony. They were maintained at $22 \pm 2^{\circ} \mathrm{C}$, on a 12-h light/12-h dark cycle, with free access to food and water. The "Principles of Laboratory Animal Care" (NIH publication no. 80-23, revised 1996) were followed in all experiments, and our research protocol was approved by the Ethical Committee for Animal Experimentation of the Centro Universitário Metodista - IPA, Porto Alegre, Brazil (13/2011). All efforts were made to minimize animal suffering and to use only the number of animals necessary to produce reliable scientific data.

\section{Tissue preparation}

The animals were euthanized by decapitation, and the brain was rapidly excised on a Petri dish placed on ice. The hippocampus was dissected, and kept chilled until homogenization which was performed in $1.5 \% \mathrm{KCl}$, using a ground glass type Potter-Elvejhem homogenizer (Kimble Chase Life Science, Rockwood, TN, USA). The homogenates were centrifuged at $800 \times \mathrm{g}$ for 10 minutes at $4^{\circ} \mathrm{C}$; the pellet was discarded and the supernatants were kept at $-70^{\circ} \mathrm{C}$ until the determinations.

\section{Incubation}

The hippocampus homogenates were pre-incubated at $37^{\circ} \mathrm{C}$ for 30 minutes with AAE $(10 \mathrm{mg} / \mathrm{mL})$ and then incubated for 60 minutes at $37^{\circ} \mathrm{C}$, with $5 \mathrm{mM}$ sodium azide and the continued presence of AAE.

\section{Oxidative stress measurements}

Thiobarbituric acid reactive substances (TBARS) measurement: For the TBARS assay, trichloroacetic acid $(10 \% \mathrm{w} / \mathrm{v})$ was added to the homogenate to precipitate proteins and to acidify samples [15]. This mixture was then centrifuged $(1000 \times \mathrm{g}, 3$ minutes). The protein-free sample was extracted and TBA $(0.67 \% \mathrm{w} / \mathrm{v})$ was added to the reaction medium. Tubes were placed in a water bath $\left(100^{\circ} \mathrm{C}\right)$ for 30 minutes.
Absorbance was read at $535 \mathrm{~nm}$ in a spectrophotometer (T80 UV/ VIS Spectrometer, PG Instruments, Alma Parck, Lutterworth, UK). Commercially available malondialdehyde was used as a standard. Results were expressed as $\mathrm{mmol} / \mathrm{L}$ protein.

Carbonyl assay: The carbonyl assay was used to determine oxidative damage to proteins. Homogenates were incubated with 2,4dinitrophenylhydrazine (DNPH, $10 \mathrm{mM}$ ) in $2.5 \mathrm{M} \mathrm{HCl}$ for 1 hour at room temperature, in the dark. Samples were mixed every $15 \mathrm{~min}$. Next, 20\% (w/v) trichloroacetic acid (TCA) was added to the tubes, which were then left in ice for 10 minutes and centrifuged for 5 minutes at $1000 \times \mathrm{g}$, to collect the protein precipitates. Another wash was performed with $10 \%$ TCA. The pellet was washed 3 times with ethanol:ethyl acetate $(1: 1)(\mathrm{v} / \mathrm{v})$. The final precipitates were dissolved in $6 \mathrm{M}$ guanidine hydrochloride, and the solutions were allowed to stand for 10 minutes at $37^{\circ} \mathrm{C}$ and then read at $360 \mathrm{~nm}$ [16]. The results were expressed as $\mathrm{nmol} / \mathrm{mg}$ protein.

Sulfhydryl assay: This assay is based on the reduction of 5,5' -dithiobis(2-nitrobenzoicacid) (DTNB) by thiols, generating a yellow derivative (TNB), whose absorption is determ.inedspectrophotometrically at 412 $\mathrm{nm}$ [17]. Briefly, $0.1 \mathrm{mM}$ DTNB was added to $120 \mu \mathrm{L}$ of the samples. This was followed by a 30-minute incubation at room temperature in a dark room and absorbance was measured at $412 \mathrm{~nm}$. The sulfhydryl content is inversely correlated to oxidative damage to proteins. Results were reported as $\mathrm{mmol} / \mathrm{mg}$ protein.

Determination of antioxidant enzyme activities: Superoxide dismutase (SOD) activity, expressed as USOD/mg protein, was based on the decrease in the rate of autocatalytic adrenochrome formation at $480 \mathrm{~nm}$ [18]. Catalase (CAT) activity was determined by following the decrease in hydrogen peroxide $\left(\mathrm{H}_{2} \mathrm{O}_{2}\right)$ absorbance at $240 \mathrm{~nm}$ and expressed as CAT/mg protein [19].

Nitric oxide production: Nitric oxide was determined by measuring the stable product nitrite using the colorimetric assay described by Hevel and Marletta (1994) [20]. Briefly, the Griess reagent was prepared by mixing equal volumes of $1 \%$ sulfanilamide in $0.5 \mathrm{~N}$ $\mathrm{HCl}$ and $0.1 \% \mathrm{~N}-(1$-naphthyl)ethylenediamine in deionized water. The reagent was added directly to the homogenates and incubated under reduced light at room temperature for $30 \mathrm{~min}$. Samples were analyzed at $550 \mathrm{~nm}$ on a microplate spectrophotometer. Controls and blanks were run simultaneously. Nitrite concentrations were calculated using a standard curve prepared with sodium nitrite $(0-80 \mathrm{mM})$. Results were expressed as $\mathrm{nmol} / \mathrm{mg}$ protein.

\section{Cell viability assays}

Methylthiotetrazol salt method (MTT): The viability assay was performed by the colorimetric 3(4,5-dimethylthiazol-2-yl)-2,5diphenyl tetrazolium bromide (MTT) method. Immediately after preincubation and incubation of the homogenates, $5 \mathrm{mg} / \mathrm{mL}$ MTT was added to the medium, followed by incubation at $37^{\circ} \mathrm{C}$ for $30 \mathrm{~min}$. The formazan product generated during the incubation was measured at 490 and $630 \mathrm{~nm}$ [21].

Lactate dehydrogenase assay (LDH): Viability was assessed by measuring the release of the enzyme lactate dehydrogenase (LDH) into the medium. $\mathrm{LDH}$ measurement was carried out in $25 \mu \mathrm{L}$ aliquots using the LDH kit from Doles Reagents [21].

Protein determination: Protein concentration was determined by the method of Lowry et al. (1951) [22] using bovine serum albumin as standard. 
Machado FS (2015) Antioxidant and neuroprotective potential of extract of Brazilian pine Araucaria angustifolia bracts against oxidative stress induced by sodium azide in hippocampus of rats

Statistical analysis: Data from the experiments were analyzed statistically by two-way analysis of variance (ANOVA) followed by the Tukey test. Values of $\mathrm{P}<0.05$ were considered significant. All analyses were carried out using the Statistical Package for Social Sciences (SPSS) software (version 17.0, International Business Machines Corporation, New York, NY, USA).

\section{Results and discussion}

The great variety of plant derivatives, their mechanism of action and their toxicity have been a challenge to pharmacology, chemistry and biochemistry [23]. The study of phenolic compounds has been of great interest because of their antioxidant properties. However, these substances have a vast array of functions in plants, including protection from predation and environmental factors [24].

Assays using a stressor that causes injury or cell death have been employed as an important experimental tool in evaluating the antioxidant properties of various natural products. Therefore, in the present study we used sodium azide treatment as an in vitro experimental model for oxidative damage. This compound acts by inhibiting complex IV (cytochrome oxidase) in the electron transport chain leading to hypoxia, by inhibiting the formation of adenosine triphosphate (ATP), and promoting an increase in reactive species, including superoxide anion and hydrogen peroxide, which may cause oxidative stress and cell death [25].

TBARS and the carbonyl technique were used to evaluate lipid and protein damage, respectively (Figure 1). Figure 1 demonstrates that sodium azide increased TBARS but not carbonyl levels. AAE prevented the increase in TBARS (Figure 1A). These results are in agreement with Souza et al. (2014) [5], who observed that the same AAE prevented the oxidative damage to lipids and proteins induced by hydrogen peroxide in MRC5 human lung fibroblast cells.

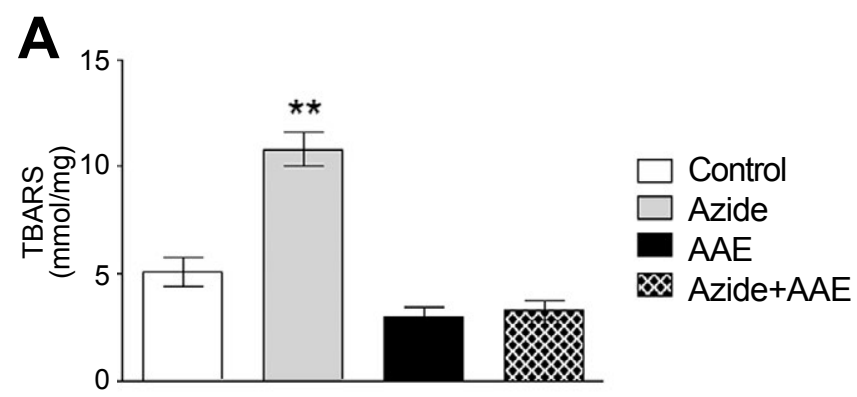

B

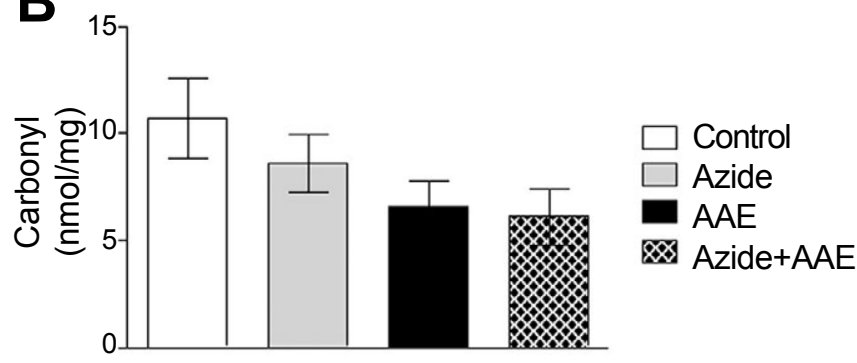

Figure 1. Effect of A. angustifolia bract extract (AAE) and sodium azide on thiobarbituric acid reactive substances (A) and on carbonyl levels (B) in rat hippocampal homogenate. Data are expressed as mean \pm SD and were statistically analyzed by two-way analysis of variance (ANOVA) followed by the Tukey post-test. $* * \mathrm{p}<0.01$, different from the other groups.

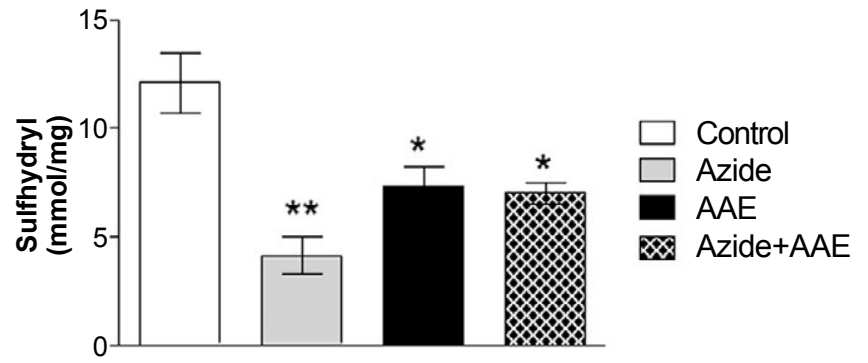

Figure 2. Effect of A. angustifolia bract extract (AAE) and sodium azide on the sulfhydryl levels in rat hippocampal homogenate. Data are expressed as mean \pm SD and were statistically analyzed by two-way analysis of variance (ANOVA) followed by the Tukey post-test. ${ }^{*} \mathrm{p}<0.05,{ }^{* *} \mathrm{p}<0.01$, different from the control.

Thiols (SH) are a class of organic sulfur derivatives characterized by the presence of sulfhydryl residues. In biological systems, SH have numerous functions, including a central role in coordinating the antioxidant defense network. To protect the cellular proteins that contain $\mathrm{SH}$ groups from excessive oxidation, the mammalian biological system has a system that regulates the redox state of cellular $\mathrm{SH}$. This system includes low-molecular weight donors of SH groups and enzymes that can catalyze the reduction of SH groups of proteins and pro-oxidants [26]. Thus, in this study the sulfhydryl assay was used to evaluate the non-enzymatic antioxidant defenses. It was observed that sodium azide reduced the sulfhydryl levels in rat hippocampal homogenate and that AAE was not able to prevent this damage (Figure 2). Moreover, AAE itself also reduced sulfhydryl content (Figure 2).

This result is in line with Jeong et al. (2014) [27], who studied the beneficial properties of Chamaecyparis leaf extract against oxidative stress caused by glutamate in rat hippocampal cells. They found that glutamate reduced GSH levels, but that the leaf extract, although being rich in catechin, was not able to prevent this depletion. On the other hand, Zaidi et al. (2014) [28] used a crude extract of Solanumnigrum and found that the extract modulated GSH levels in rat brain, even after the animals were subjected to immobilization stress.

To determine the enzymatic antioxidant defenses, the activities of the enzymes CAT and SOD were evaluated, since they are the most important enzymes of the cell antioxidant defense system. These enzymes represent the first barrier against reactive species and are essential to cell survival $[29,30]$. The enzyme SOD catalyzes the dismutation of superoxide anion into oxygen and hydrogen peroxide. The enzyme CAT catalyzes the reduction of hydrogen peroxide to water and molecular oxygen $[13,14]$. In the present study, it was demonstrated that sodium azide increased CAT activity (Figure $3 \mathrm{~A}$ ) and reduced SOD activity (Figure $3 \mathrm{~B}$ ) in rat hippocampal homogenate, and that these alterations were prevented by AAE (Figure 3).

The same protection was observed by Souza et al. [5], where AAE prevented the alterations of CAT and SOD induced by hydrogen peroxide. Michelon et al. [7] reported an increase in the SOD/CAT ratio, demonstrating that AAE has antioxidant potential and also a role in the maintenance of the redox balance, reducing oxidative stress.

Next, we investigated whether nitric oxide $(\mathrm{NO})$ synthesis could be induced by sodium azide, since SOD activity can be altered by peroxynitrite, the most harmful NO derivative $[31,32]$. Increases in the production of reactive nitrogen species result from excess NO reacting with reactive oxygen species. NO is a signaling molecule that reacts 

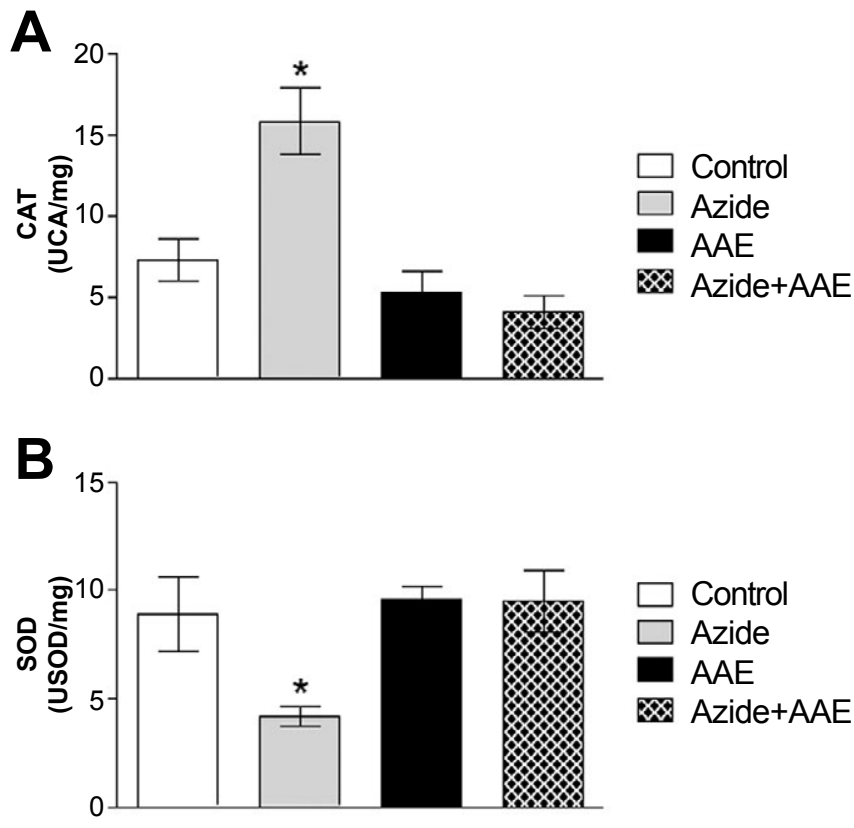

Figure 3. Effect of A. angustifolia bract extract (AAE) and sodium azide on catalase (CAT) (A) and superoxide dismutase (SOD) (B) activities in rat hippocampal homogenate. Data are expressed as mean \pm SD and were statistically analyzed by two-way analysis of variance (ANOVA) followed by the Tukey post-test. ${ }^{*} \mathrm{p}<0.05$, different from all other groups.

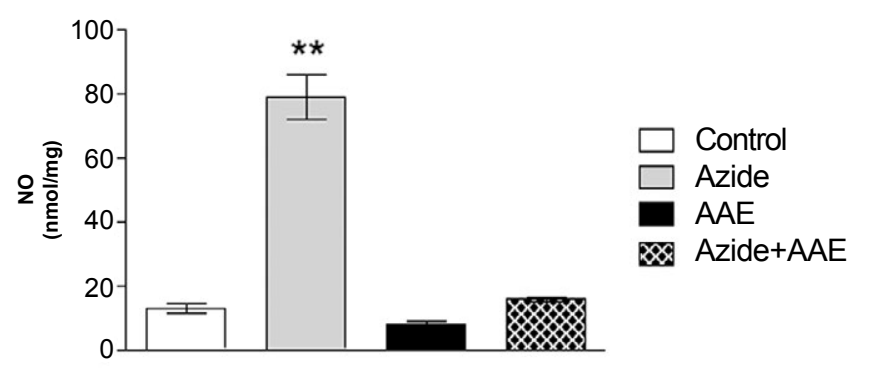

Figure 4. Effect of the A. angustifolia bracts extract (AAE) and sodium azide on the levels of nitric oxide (NO) in rat hippocampal homogenate. Data are expressed as mean $\pm \mathrm{SD}$ and were statistically analyzed by two-way analysis of variance (ANOVA) followed by the Tukey post-test. ${ }^{* *} \mathrm{p}<0.01$, different from all other groups.

with superoxide anion to generate reactive nitrogen species, including peroxynitrite, which is a very reactive molecule that can modify biomolecules, including lipids and proteins $[31,33,34]$.

In this study, sodium azide enhanced NO production in the rat hippocampal homogenate and AAE was able to prevent this increase (Figure 4). In this context, Paquay et al. [35] showed that green tea (Camelia sinensis) has in vitro antioxidant properties by inhibiting NO production.

It cannot be excluded that the oxidative damage caused by sodium azide could in part lead to the death of neural cells. Therefore, two different assays were used to analyze the effect of sodium azide and AAE on the viability of the homogenates. Figure 5 demonstrates that sodium azide did not change LDH activity and MTT reduction levels in the rat hippocampal homogenate. However, AAE inhibited $\mathrm{LDH}$ release (Figure 5A) and increased MTT reduction in the presence or absence of sodium azide (Figure 5B), indicating that the extract enhanced cell
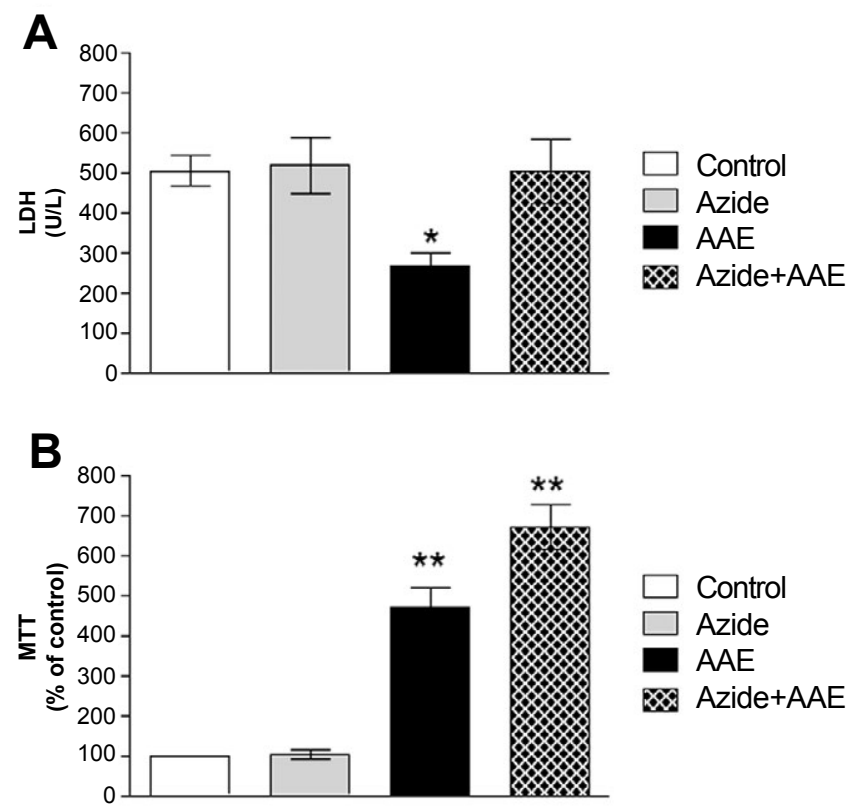

Figure 5. Effect of $A$. angustifolia bract extract (AAE) and sodium azide on the LDH activity of (A) and MTT (B) in rat hippocampal homogenate. Data are expressed as mean \pm $\mathrm{SD}$ and were statistically analyzed by two-way analysis of variance (ANOVA) followed by Tukey post- test. ${ }^{*} \mathrm{p}<0.05,{ }^{* *} \mathrm{p}<0.01$, different from the control.

viability and showed some beneficial properties against cell death. This is in line with the finding that AAE significantly protected MRC5 human lung fibroblast cells against hydrogen peroxide-induced mortality and oxidative damage to lipids, proteins, and DNA [5].

Taken together, sodium azide significantly compromised the nonenzymatic (sulfhydryl) and enzymatic (CAT and SOD) antioxidant defenses, increasing the levels of reactive species, but did not induce cell death in the rat hippocampal homogenate. As a result, there was an imbalance between pro-oxidants and antioxidants, a situation defined as oxidative stress [36]. Moreover, AAE was able to prevent the oxidative changes induced by sodium azide, and therefore, it can be concluded that the intake of polyphenol-rich foods could reduce, delay or even inhibit the development of some diseases related to oxidative stress.

\section{Acknowledgment}

This work was supported by Centro Universitário Metodista IPA, CAPES, FAPERGS and CNPq. Dr. A. Leyva helped with English editing of the manuscript.

\section{References}

1. Schenkel EP, Gosmann G, Petrovick PR (2001) Produto de origem vegetal e o desenvolvimento de medicamentos. In: Simões CMO, Schenkel EP, Gosmann G, Mello JCP, Mentz LA, Petrovick PR. (org) Farmacognosia: da planta ao medicamento. 3.ed. Porto Alegre/Florianópolis: Editora da Universidade UFRGS/ editora da UFCS: 301-302.

2. Silva MLC, Costa RS, Santana AS, Koblitz MGB (2010) Compostos fenólicos, carotenoides e atividade antioxidante em produtos vegetais. Ciências Agrárias 31: 669-682.

3. Dummer CD, Thomé FS, Veronese FV (2007) Chronic renal disease, inflammation and atherosclerosis: new concepts about an old problem. Rev Assoc Med Bras 53: 446-450. [Crossref]

4. Cozzo D (1979) Distribución fitogeográfica enla Argentina de Araucaria araucana y A. angustifolia. In: iufro meeting on forestry problems of the genus araucaria. Forestry problems of the genus Araucaria. FUPEF: 1-34. 
Machado FS (2015) Antioxidant and neuroprotective potential of extract of Brazilian pine Araucaria angustifolia bracts against oxidative stress induced by sodium azide in hippocampus of rats

5. Souza MO, Branco CS, Sene J, Dall Agnol R, Agostini F, et al. (2014) Antioxidant and antigenotoxic activities of the Brazilian pine Araucaria angustifolia (Bert.) O. Kuntze. Antioxidants 3: 24-37.

6. IBGE- Instituto Brasileiro de Geografia e Estatística. Available online: http://www. ibge.gov.br/estadosat/temas.php?sigla=rs\&tema=extracaovegetal2010 (accessed on June 10, 2013).

7. Michelon F, Branco CS, Calloni C, Giazzon I, Agostini F, et al. (2012) Araucaria angustifolia, a potential nutraceutical with antioxidant and antimutagenic activities. Curr Nutr Rep 8: 155-159.

8. Marquesini NR (1995) Medicinal Plants Used by the Indians as the Parana and Santa Catarina, Southern Brazil: Guarani, Kaingang, Xokleng, Ava-Guarani, Kraô and Cayuá. Master's Thesis, University Federal do Paraná, Curitiba, Brazil.

9. Zern TL, Fernandez ML (2005) Cardioprotective effects of dietary polyphenols. J Nutr 135: 2291-2294. [Crossref]

10. Silver HJ, Dietrich MS, Niswender KD (2011) Effects of grapefruit, grapefruit juice and water preloads on energy balance, weight loss, body composition, and cardiometabolic risk in free-living obese adults. Nutr Metab (Lond) 8: 8. [Crossref]

11. Lau FC, Shukitt-Hale B, Joseph JA (2005) The beneficial effects of fruit polyphenols on brain aging. Neurobiol Aging 26 Suppl 1: 128-132. [Crossref]

12. Venturini CD, Merlo S, Souto AA, Fernandes MC, Gomez R, et al. (2011). Resveratrol and red wine function as antioxidants in the central nervous system without cellular proliferative effects during experimental diabetes. Oxid Med Cell Longev 3: 434-441.

13. Halliwell B (2007) Dietary polyphenols: good, bad, or indifferent for your health? Cardiovasc Res 73: 341-347. [Crossref]

14. Valko M, Leibfritz D, Moncol J, Cronin MT, Mazur M, et al. (2007) Free radicals and antioxidants in normal physiological functions and human disease. Int J Biochem Cell Biol 39: 44-84.

15. Buege JA, Aust SD (1978) Microsomal lipid peroxidation. Methods Enzymol 52: $302-$ 310. [Crossref]

16. Reznick AZ, Packer L (1994) Oxidative damage to proteins: spectrophotometric method for carbonyl assay. Methods Enzymol 233: 357-363. [Crossref]

17. Aksenov MY, Markesbery WR (2001) Changes in thiol content and expression of glutathione redox system genes in the hippocampus and cerebellum in Alzheimer's disease. Neurosci Lett 302: 141-145. [Crossref]

18. Bannister JV, Calabrese L (1987) Assays for superoxide dismutase. Methods Biochem Anal 32: 279-312. [Crossref]

19. Aebi H (1984) Catalase in vitro. Methods Enzymol 105: 121-126. [Crossref]

20. Hevel JM, Marletta MA (1994) Nitric-oxide synthase assays. Methods Enzymol 233: 250-258. [Crossref]
21. Funchal C, Rosa AM, Wajner M, Wofchuk S, Pureur RP (2004) Reduction of glutamate uptake into cerebral cortex of developing rats by the branched-chain alpha-keto acids accumulating in maple syrup urine disease. Neurochem Res 29: 747-753. [Crossref]

22. Lowry OH, Rosebrough NJ, Farr al, Randall RJ (1951) Protein measurement with the Folin phenol reagent. J Biol Chem 193: 265-275. [Crossref]

23. Trindade RA (2005) Análise comparativa da atividade antioxidante do extrato aquoso de orégano e alecrim em sistema a $\beta$-caroteno/ácido linoléico. Arquivo do Instituto Biológico. Reunião Anual do Instituto Biológico72: 1-64.

24. Simões CMO (2010) Farmacognosia, da planta ao medicamento. Sixth ed., Porto Alegre: UFRGS: 1004

25. Nelson DL, Cox MM (2011). Princípios de bioquímica de Lehninger, fifth ed., Porto Alegre: Artmed: 1304

26. Zugno AI, Stefanello FM, Scherer EB, Mattos C, Pederzolli CD, et al. (2008) Guanidinoacetate decreases antioxidant defenses and total protein sulfhydryl content in striatum of rats. Neurochem Res 33: 1804-1810. [Crossref]

27. Jeong EJ, Hwang L, Lee M, Lee KY, Ahn MJ, et al. (2014) Neuroprotective biflavonoids of Chamaecyparis obtusa leaves against glutamate-induced oxidative stress in HT22 hippocampal cells. Food Chem Toxicol 64: 397-402. [Crossref]

28. Zaidi SK, Hoda MN, Tabrez S, Ansari SA, Jafri MA, et al. (2014) Protective Effect of Solanum nigrum Leaves Extract on Immobilization Stress Induced Changes in Rat's Brain. Evid Based Complement Alternat Meddoi: 10.1155/2014/912450.

29. Halliwell B (2001) Role of free radicals in the neurodegenerative diseases: therapeutic implications for antioxidant treatment. Drugs Aging 18: 685-716. [Crossref]

30. Remacle J, Michiels C, Raes M (1992) The importance of antioxidant enzymes in cellular aging and degeneration. EXS 62: 99-108. [Crossref]

31. Ischiropoulos H, Zhu L, Chen J, Tsai M, Martin JC, et al. (1992) Peroxynitritemediated tyrosine nitration catalyzed by superoxide dismutase. Arch Biochem Biophys 298: 431-437. [Crossref]

32. Yamakura F, Matsumoto $T$, Ikeda K, Taka H, Fujimura T, et al. (2005) Nitrated and oxidized products of a single tryptophan residue in human $\mathrm{Cu}, \mathrm{Zn}$-superoxide dismutase treated with either peroxynitrite-carbon dioxide or myeloperoxidase-hydrogen peroxide-nitrite. J Biochem 138: 57-69. [Crossref]

33. Barnes PJ, Shapiro SD, Pauwels RA (2003) Chronic obstructive pulmonary disease: molecular and cellular mechanisms. Eur Respir J 22: 672-688. [Crossref]

34. Yeo WS, Lee SJ, Lee JR, Kim KP (2008) Nitrosative protein tyrosine modifications biochemistry and functional significance. BMB Rep 41: 194-203. [Crossref]

35. Paquay JB, Haenen GR, Stender G, Wiseman SA, Tijburg LB, et al. (2000) Protection against nitric oxide toxicity by tea. J Agric Food Chem 48: 5768-5772. [Crossref]

36. Sies H (1991) Oxidative stress: from basic research to clinical application. Am J Med 91: 31S-38S. [Crossref]

Copyright: (C2015 Machado FS. This is an open-access article distributed under the terms of the Creative Commons Attribution License, which permits unrestricted use, distribution, and reproduction in any medium, provided the original author and source are credited. 